\title{
Introduction: South Asia and the Americas
}

\author{
Brian Yothers \\ Department of English \\ University of Texas at El Paso \\ Pramod K. Nayar \\ Department of English \\ University of Hyderabad, India
}

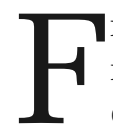

rom John Donne's appropriation of "both the Indias of Spice and mine" as a metaphor for erotic fulfillment to the unexpected success of Slumdog Millionaire at the 2009 Academy Awards, South Asia and the Americas have been linked discursively in Anglophone literature and film despite their geographic distance from each other. Throughout the nineteenth century, South Asian religious and philosophical traditions contributed substantially to shaping the thought of such central American literary figures as Ralph Waldo Emerson, Margaret Fuller, Henry David Thoreau, Walt Whitman, and Herman Melville. Trade and missionary accounts brought back from South Asia meant that even so reclusive a literary figure as Emily Dickinson found occasion to mention Ceylon (Sri Lanka) in her letters. By the late nineteenth century, travel between the Americas and South Asia had become a two-way affair, and the amount of traffic has been increasing ever since. The articles in this issue span a period from the late nineteenth century to the early twenty-first century, and they address four important modes of travel and cultural exchange between South Asia and the English-speaking portions of the Americas.

Walter S. H. Lim and Maryse Jayasuriya examine narratives of immigration from South Asia to the United States from the 1970s to the present. Malini Johar Schueller and S. Walter Perera critique the touristic discourses associated with travel to South Asia. Amardeep Singh and Brian Yothers explore the 


\section{Introduction}

cultural exchange and critique arising from late nineteenth and early twentieth century travel writing and lecture tours. Nandana Dutta, meanwhile, examines the continuing significance of missionary travel - whose first "occurrence" in the nineteenth century under British colonial rule altered the cultural landscape of the region to an unimaginable extent - to Assam.

Immigration, particularly for economic purposes, has been central to the cultural exchanges between South Asia and the United States and Canada in the late twentieth and early twenty-first centuries. The significance of immigration to the North American/South Asian encounter means that South Asia's engagement with the United States and Canada has become entangled with the wider question of economic migration to North America, both from portions of Asia other than South Asia and from other portions of the Americas. Walter S. H. Lim pairs Bharati Mukherjee, a central figure in the first generation of South Asian immigrant writers in North America, with the Malaysian writer Shirley Geok-Lin Lim. He thus demonstrates the continuities across the wider field of Asian-American writing between South Asian and Southeast Asian immigrant fiction, and he argues that Mukherjee and Lim both provide contexts for understanding the United States as a "locus for immigrant desire." Maryse Jayasuriya, on the other hand, examines two more recent literary works, Kiran Desai's Man Booker Prize-winning The Inheritance of Loss and Sri Lankan short-story writer Ameena Hussein's little-known Zillij, in order to understand the role of class in recent South Asian fiction set in the United States. Jayasuriya's article illuminates the connections between working class South Asian immigrants and their counterparts from Central and South America and the Caribbean that Desai and Hussein foreground in their respective works.

Malini Johar Schueller complicates the question of Asian and American identities through a discussion of travel writing about South Asia by the celebrated travel writer Pico Iyer, whose South Asian heritage and residence in the United States makes him a case study in the interconnectedness of South Asia and the Americas. Schueller contends that Iyer's work raises urgent questions about the nature of globalization and its relation to colonialism and neo-colonialism. S. Walter Perera's critique of touristic responses to Sri Lanka also reflects upon the role of globalization in defining the relationship between South Asia and the Americas, tying the tropes used by a Caribbean writer of Indian origin, Shiva Naipaul, to works by British and Australian travelers to Sri Lanka. 
Amardeep Singh's article provides a concise survey of Indian writing about the United States around the turn of the twentieth century before proceeding to a suggestive analysis of Rabindranath Tagore's lecture tour in the United States and the travel narrative that came out of it. Brian Yothers considers one of the major late nineteenth-century Indian travelers to the United States, Pandita Ramabai, in relation to her contemporary Mark Twain and his voyage to India and Ceylon (Sri Lanka) in the 1890s, arguing that the juxtaposition of these two witty and sophisticated travelers undermines facile distinctions between Eastern and Western modes of travel writing. Lastly, no consideration of the relation of South Asia to North America would be complete without a discussion of the role of American missionaries in the context of British colonial power. Nandana Dutta's article suggests that American Baptist missionaries in Assam in the nineteenth and twentieth centuries played a very different role from their British counterparts.

What ultimately emerges from this collection of articles is a cross-section of the encounters between South Asia and the Americas over more than a century. Immigration, tourism, education, and missionary encounters all contribute to a relationship between the Americas and the South Asian subcontinent that is ineluctably shaped by both the experience and the representation of travel and that opens out into the wider currents of a globalized and globalizing world. This issue consciously works across genres - travel narratives, fiction, memoirs - in order to show how "America" figures within the South Asian literary-cultural imagination, even as the American imagination is shaped by the consistent and irreducible presence of South Asia within it. 